Валентин Златніков, кандидат педагогических наук, доцент, Військовий інститут, Київський національний університет імені Тараса Шевченка, м. Київ ORCID ID 0000-0001-7019-9551

Ольга Кузнєцова, кандидат психологічних наук, доцент, Інститут філології, Київський національнийуніверситет імені Тараса Шевченка, м. Київ ORCID ID 0000-0001-5730-8696

DOI: 10.33099/2617-1775/2019-02/91-99

\title{
ІННОВАЦІЙНІ ТЕХНОЛОГІЇ У ЗАСВОСННІ СЛУЖБОВОЇ ТА ПРОФЕСІЙНОЇ ЛЕКСИКИ ІНОЗЕМНОЮ МОВОЮ
}

Дана стаття розглядає інноваційні підходи навчання іноземних мов для засвоєння службової та професійної лексики відповідно вимогам навчальних програм не фахових факультетів; надана схема навчання усного мовлення англійською за фахом, а також базові характеристики наукового тексту, необхідного для засвоєння службової та професійної лексики

Ключові слова: динаміка мислення та комунікативні особливості; репродуктивне відтворення; засоби вираження; породження мовного вислову; дозування труднощів; наочність; мовні навички; загальнонаукова лексика.

Постановка проблеми. Спочатку треба усвідомити, яким чином можна узгодити соціальне замовлення суспільства (підготовка фахівця у короткий термін згідно вимог навчальних програм не фахових факультетів) iз мінімальною кількістю годин у чинному навчальному плані.

На сьогодні нам видається можливим домогтися поставленої мети навчити студента протягом обмеженого навчальними рамками періоду говорити на теми майбутнього фаху, розуміти мову носіїв мови завдяки інноваційним i традиційним методам навчання, 3 рішучим наголосом на принципі комунікативності як у навчальному процесі, так йу складанні навчальних матеріалів і навчальних посібників.

Вивчення особливостей усної наукової мови має враховувати новітні дані психологічної та методичної науки, 3 одного боку, i комунікативні особливості мови спеціальності відповідно до профілю навчання, 3 іншого,що потребує подальшої дослідної практики.

Аналіз останніх досліджень і публікацій. Досліджуючи загально методичні та загально психологічні тези про зв'язок мовлення з мисленням, про співвідношення слова та його значення, співвідношення поняттята уяви, про основні закономірності практичного використання слів, про особливості мислення іноземною мовою тощо, ми маємо можливість ознайомитися із провідними науковими теоріями з методики викладання іноземних мов у не фахових ВН3. 
Сучасна наукова думка наголошує, що оволодіння іноземною фаховою лексикою являє собою основне завдання цього навчання. У вітчизняних методиках, як правило, відсутнє психологічне обгрунтування методики навчання військової/фахової лексики іноземної мови, в результаті - не лише курсанти/студенти, а й молоді фахівці стикаються, як кажуть, із "труднощами перекладу", тобто, з трудом засвоюють фахову мову самостійно, недосконало володіють нею на практиці, де допускаються мовні форми, не властиві даній мові, а переклади часто виявляються незрозумілими, беззмістовними.

Такі невдачі $є$ результатом того, що курсанти/студенти, використовуючи аудіовізуальні методи запам'ятовування термінів, не до кінця розуміють їх смислову сторону, тобто не оволодівають поняттями, що висловлюють дані мовні форми, а це означає, що вони не можуть мислити та спілкуватися на теми 3 фаху іноземною мовою.

Не буде помилковим твердження, що, поряд 3 відносно правильною вимовою та знанням граматики, студенти не в змозі оволодіти системою спеціальної/фахової іноземної мови.

Тому не менш важливим завданням в цьому відношенні $є$ проблема розуміння студентами смислової сторони засвоюваних ними слів та термінів іноземної мови. Від цього розуміння залежить утворення в їхній свідомості тих понять, які відповідають словам іноземної мови, на основі яких можливе мислення та практика фахової мови іноземною, отже, назріває питання про способи семантизації фахових термінів та висловів.

Таких способів у сучасній вітчизняній методиці багато. Якщо коротко, найтрадиційнішим способом $\epsilon$ переклад, заміна іноземного слова/терміна відповідним словом рідної мови. Такий спосіб був прийнятий ще в середньовічній схоластиці у навчанні латинської мови, багатократне механічне повторення, а потім й заучування слів. У новітні часи, з початку 18-го століття, його також прийняли. Зберігся цей спосіб й до наших днів.

Авторитетних прихильників такого методу навчання у сучасній методиці ще досить багато.Практично він домінує скрізь - при складанні двомовних словників, хоча іноді надається кілька варіантів перекладу (наприклад, при складанні підручників, при адаптації художніх текстів).

На захист такого методу можна сказати: цілком природне прагнення того, аби курсант/студент вчився осмислювати нові словосполучення за допомогою звичного йому мислення рідною мовою.

Службове/фахове мовлення в навчальному вигляді повинно розумітися як слухання і читання, розуміння і репродуктивне відтворення прослуханого або прочитаного у формах як усного діалогічного або монологічного мовлення, так й у письмовій.

Таким чином, мова йде про реалізацію мовного акту говоріння в процесі усної комунікації між двома і більше особами.

Мета статті. Як відомо, метою навчання іноземних мов на неспеціальних факультетах $є$ формування комунікативної компетентності, яка включає в себе лінгвістичну, тематичну (екстралінгвістичну i країнознавчу інформацію), 
соціокультурну, компенсаторну, навчальну (вміння навчатися як у групі,так i самостійно/індивідуально).

Курсант/студент повинен оволодіти такими навичками й вміннями, які дозволили б найбільш успішне спеціалізоване самовдосконалення, дали б можливість донавчання та самонавчання іноземної мови у декількох напрямках-підтримка i вдосконалення досягнутого рівня комунікативної компетенції; вивчення нової іноземної мови.

Метою даної статті $\epsilon$ визначення інноваційних підходів навчання іноземних мов у засвоєнні службової та професійної лексики для неспеціальних цілей.

Виклад основного матеріалу. Системні зміни, що відбуваються у процесі розбудови сучасного суспільства, безумовно, вимагають прискореного вдосконалення освітнього простору, визначення цілей освіти (як спеціальної,так і фахової), які б враховували державні, соціальні та кар'єрні потреби і інтереси самого майбутнього фахівця. У зв’язку з цим пріоритетним напрямком стає забезпечення розвиваючого потенціалу нових освітніх стандартів.

Системно - діяльнісний підхід, який лежить в основі розробки стандартів нового покоління, дозволяє виділити основні результати навчання і виховання, створити так звану “дорожню карту” проектування універсальних навчальних дій, якими повинні володіти курсанти /студенти.

Отже, на початку предметом наукового обговорення мають стати певні універсальні навчальні дії, наприклад:

- особистісні - формування смислу на основі розвитку мотивації i постановки цілейй вчення;

-регулятивні - постановки цілей і побудови кар'єрних та життєвих планів у часовій перспективі;

-пізнавально-дослідницькі дії - пошук інформації, дослідження;

- комунікативні дії, що спрямовані на здійснення міжособистісного спілкування, на кооперацію, дії, що забезпечують формування особистісної та пізнавальної рефлексії.

Запровадженні дидактичні дії надалі полегшать побудову схеми навчання як загальної англійської (читання та письмо включно), так і усного мовлення за фахом, які, у свою чергу, можуть будуватися, враховуючи наступне:

- визначення комунікативних ознак для більшості типів текстів даної спеціальності і засобів вираження цих ознак, тобто комунікативних моделей;

- визначення ознак усного мовлення і засобів вираження цих ознак;

- зіставлення засобів вираження i відбір моделей для пасивногота активного тренування;

- визначення переліку комунікативних ознак і моделей усного службового мовлення та по спеціальності;

- розробка системи вправ для їх активного засвоєння;

- відбір та складання різних комунікативно-орієнтованих текстів з фаху, окремих видів текстів у навчальних цілях, визначення їх основних 
комунікативних особливостей, моделей, надалі, розробка ефективної системи вправ для тренування вибраних структурних одиниць;

- створення мовної бази попередньо отриманих (загальних) знань для вироблення мовленнєвих умінь i навичок, тобто, відбір i тренування словотворчих, лексичних та граматичних структур, необхідних для службового/спеціального читання, розуміння, аудіювання та говоріння;

- вироблення, тренування доавтоматичного відтворення у курсанта/студента навчальних алгоритмів за всіма видами мовленнсвої діяльності;

- усна комунікація від монологу до діалогу на фахові теми із запровадженням проблемно-пошукових завдань.

Якщо описувати систему вправ на етапі доопрацювання тексту, треба пам'ятати, що викладачеві необхідно знати принципи їх загальної побудови: дозування труднощів на кожному етапі навчання від однісї проблеми в одній вправі до розпізнавання схожих по виду явищ, про циклічність повторення матеріалу, що вивчається у малих дозах протягом тривалого часу, про доведення навички до автоматизму, про ускладнення вправ тощо, хоча неодмінною вольовою умовою має залишатися комунікативна орієнтованість на усне мовлення у рамках конкретних мовних ситуацій з фаху.

Викладачу немовних ВНЗ має добре знати специфіку наукових, науковотехнічних та фахових текстів, які вивчаються, i, за потреби, вводити їх в процесі навчання, тобто одночасно знайомити студентів з новими патернами розуміння фахового/службового матеріалу. Це може бути спеціальна термінологія (військова), особлива загально-наукова лексика, специфічна службова лексики, ті чи інші складні граматичні конструкції.

Основою навчання в умовах немовного оточення буде текст 3 фаху іноземною мовою. Викладач має відібрати саме ті види та типи текстів 3 фаху мовою, що вивчається, які допоможуть курсанту/студенту реалізувати комунікативні можливості говоріння.

По засобу передачі тексти можна розрізняти на:

- усні і письмові;

- за характером викладу: опис, повідомлення, розповідь, міркування, їх поєднання з іншими спеціальними видами текстів, таких як анотації, рецензії тощо;

- за ступенем їх специфіки і відношення до адресата: дослідні, наприклад, монографії, наукові статті, навчальні, тобто статті і тексти 3 підручників, довідників, словників тощо.

Необхідно розпочинати із найпростіших описів і характеристик у форматі монологічного опрацювання на самому початковому етапі. Потім можна вивчати і більш складні за структурою і стилем тексти, але намагатися сформувати у студента модель його діяльності в форматі комунікативної пари “викладач / аудіо і мультимедійні засоби", “студент-студент ”.

Для роботи в аудиторії треба ретельно підбирати професійно релевантний матеріал, враховувати попередні знання курсанта/студента 3 мови 
та спеціальності, його вік, мету комунікації, вид комунікації, ступінь навчання та інше. Після відбору словотворчих, лексичних та граматичних структур, необхідних для засвоєння текстів, що опрацьовуються, починається їх тренування. Слід постійно пам'ятати про діалогічну форму вправ, в тому числі i при введенні фахової лексики.

Таким чином, буде доречно тренувати не тільки термінологічну i загальнонаукову лексику, а й службову лексику наукової прози та модальнооцінюючу лексику усної форми спілкування.

Науковий текст англійською мовою $\epsilon$ специфічний i, як правило, характеризується:

- мовною економією, що виражається, наприклад, в номінативному характері пропозиції;

-особливості термінологічних систем, спеціальних мовних штампах;

- своєрідною наочністю : графічні засоби членування тексту і абзацу;

- докладністю викладу: схеми, таблиці, повтори, заміна одних структурних одиниць іншими.

Усна ж мова має інші особливості: переважання простого припущення, ситуативна незавершеність відрізків фрази, особлива емоційна забарвленість тощо, що описано в роботах багатьох методистів та лінгвістів.

Вже на стадії попереднього тренування структур мовного акту виникає необхідність у порівнянні комунікативних ознак наукового тексту та усного мовлення за даною спеціальністю. Надалі, певна частина комунікативних ознак i мовних патернів, що служать для їх вираження, кодуються у пасивному словниковому запасі, інші активно тренуються та практикуються.

Граматичною базою усного акту комунікації має служити просте речення та широко поширені типи складнопідрядних речень, які не повинні містити великого числа другорядних членів. Ряд досліджуваних структур може носити характер кліше і фразеологізмів.

Крім звичайних стандартних мовних зворотів i фразових єдностей у розмовній мовіслужбовцям для привітання, вибачення i таке інше можна запропонувати запровадження в усне мовлення за фахом активно вводити структури для вираження різних мовних дій - інформуючих, спонукальних, оціночно-модальних, контактних тощо.

Обумовлено необхідною $\epsilon$ робота зі створення базових знань курсанта/студента, що повинна проходити, особливо на початковому етапі, за чіткими правилами із озвучуванням всього навчального плану.

Починати роботу можна із читання тексту 3 перекладом, надалі, оглядового читання, але все одно треба прагнути до сприйняття інформації на слух. Тут може виправдати себе й використання інтонаційного читання сучасних інтенсивних методик. I, звичайно ж, слід ширше використовувати сучасні аудіо і мультимедійні засоби.

Науковий текст, як основна навчальна одиниця під час навчання іноземної мови, повинен, особливо на перших курсах для курсантів/студентів 3 обмеженими знаннями, озвучуватися i прослуховуватися багаторазово i 
повторюватися цілком, потім - різними блоками. Лише тоді той, якого навчають, зможе навчитися визначати основну тему тексту, його логічну структуру, що й повинно бути базою акту комунікації за фахом.

Головне полягає в умінні пізніше правильно поставити запитання (логічно і граматично), в умінні повної відповіді на поставлене до тексту запитання, тобто встигнути зрозуміти і підтримати розмову, пам'ятати про основні концептуальні тези та логіку їх викладу.

Вправи, комунікативно-орієнтовані на усне мовлення, мають обов’язково охопити наступніскладові:

- наявність (пред’явлення) вихідного матеріалу або моделі,

- за необхідності,пояснення матеріалу або моделі,

- імітація моделі,

- відтворення тієї чи іншої моделі, без зміни/зі зміною, одноосібно/ в комунікативній парі і т.д.,

- власна комунікація.

Навчання усного службового мовлення іноземною мовою, особливо за фахом в немовних ВНЗ, є складним і трудомістким процесом, оскількиу мові курсанта/студента повинні бути наявні елементи відповідного текстового жанру, тобто наукового/службового стилю. Робота викладача полегшується, якщо спеціальна мова (іноземною) може бути близька за багатьма параметрами, покладеними в основу навчання навчального тексту, й охоплювати меншу кількість довільних ситуативних можливостей.

Багато так званих побутових та щоденних ситуацій можна опрацювати в аудиторії, коли здійснюється перехід від тренувальних вправ до діалогу,йдеться про прослуховування, читання, переказ діалогів, завершення їх по заданій ситуації або мовного матеріалу, їх вільного складання за будь-яким принципом. Допускається використання повного i часткового зворотного перекладу. Головне полягає в умінні сформулювати основну тему проблеми, в умінні правильно описати їі, в умінні заперечувати, шукати причину тощо.

При розвитку навичок усного мовлення іноземною мовою за фахом необхідно пам'ятати, що іiі монологічна складова не поступається діалогічній. Тому далі треба вимагати збільшення обсягу монологічного мовлення в діалозі, а пізніше переходу до суто монологічних форм усного мовлення: резюме, реферування, анотування, опис схеми, явища або процесу, аж до запису зібраного матеріалу/інформації, що стане в нагоді при конспектуванні лекцій та виконанні творчих робіт.

Природно, що поставленої мети можна досягти тільки на основі комунікативно-орієнтованих підручників і навчальних матеріалів.

Зрозуміло, що на заняттях іноземною мовою виробляються основні навички усної комунікації, які можуть бути повністю реалізовані у практику молодого спеціаліста.

Решта видів мовленнєвої діяльності готуються та тренуються так само, оскільки є основою для розвитку навичок усного мовлення. 
Слід зауважити, що на іспиті з іноземної мови виклад теми за фахом не може служити критерієм вимірювання знань, умінь й навичок студентів у цій галузі знань, це радше одне із навчальнихзавдань. Лише у діалозі із викладачем, або у парі “студент - студент", в умінні постановки запитань, відповідях на них, при визначенні основної теми запропонованого матеріалу, анотації на нього тощо можна з'ясувати ступінь підготовленості курсанта/студента до подальшого користування іноземною службовою/фаховою мовою.

Висновки. Таким чином, викладання іноземних мов у немовних ВНЗ полягає у застосуванні інноваційних технологій, поєднаних із класичними/традиційними, та інтенсивних методів навчання, заснованих на функціонально-комунікативній лінгво-дидактичній моделі мови, у розробці цілісної системи навчання студентів мовного спілкування на професійні теми.

Напрями подальших досліджень. Протягом новітньої історії розвитку розробки наукових психологічних та методичних теорій навчання іноземної мови в немовних ВНЗ традиційно були орієнтовані на класичну практику, тобто, читання, розуміння й переклад спеціальних/фахових текстів, а також вивчення проблем синтаксису наукового стилю.

На сучасному етапі у навчанні службової/фахової іноземної мови необхідно перенести акцент на розвиток навичок мовного спілкування саме на професійні теми,на ведення наукових дискусій, тим більше, робота над ними не заважає подальшому розвитку навичок, умінь і знань курсантів/студентів, тому що базується саме на них.

\section{ЛІТЕРАТУРА}

1. Березовская M.В. Методы и приемы обучения лексике в неязыковом вузе/ Methods and techniques of vocabulary teaching // Инновации в системе непрерывного технического образования: Материалы республикан. науч.-практ. конф. /ред. Б.М. Хрусталев, В.Л. Соломахо. - Минск: Изд-во БНТУ, 2014. - С. 65-66.

2.Введение в коммуникативную методику обучения английского языка. - Oxford University Press, 1997.

3. Celce-Murcia, M., ed. (2001). Teaching English as a Second or Foreign Language. Heinle

$\&$ Heinle Publishers. Boston, Massachusetts.

https://www.scirp.org/(S(i43dyn45teexjx455qlt3d2q))/reference/ReferencesPapers.aspx?ReferenceI $\mathrm{D}=1681301$

4.Douglas H.Brown. Teaching Principles./An Interactive Approach to Language Pedagogy.Third Edition.-2007.- P.569.

5. Dudley-Evans, T. English for Specific Purposes. In R. Carter \&D. Nunan (Eds.).- The Cambridge Guide to Teaching English to Speakers of Other Languages Cambridge: Cambridge University Press. -2001. Pp. 131- 136.

6. Jones, G. ESP textbooks: Do they really exist? English for Specific or Special purpose.v.9, issue 1. - 1990. Pp. 89-93.

7. Regan, L. 20 Teaching Tips: Pair Work/Group Work. http://www.tefl.net/teaching/ teaching-tip_01.htm

\section{REFERENCES}

1. Березовская M.В. Методы и приемы обучения лексике в неязыковом вузе/ Methods and techniques of vocabulary teaching // Инновации в системе непрерывного технического образования: Материалы республикан. науч.-практ. конф. /ред. Б.М. Хрусталев, В.Л. Соломахо. - Минск: Изд-во БНТУ, 2014. - С. 65-66. 
2.Введение в коммуникативную методику обучения английского языка. - Oxford University Press, 1997.

3. Celce-Murcia, M., ed. (2001). Teaching English as a Second or Foreign Language. Heinle

\& Heinle Publishers. Boston, Massachusetts. https:/www.scirp.org/ (S(i43dyn45teexjx455qlt3d2q))/reference/ReferencesPapers.aspx?ReferenceID=1681301

4.Douglas H.Brown. Teaching Principles./An Interactive Approach to Language Pedagogy.Third Edition.-2007.- P.569.

5. Dudley-Evans, T. English for Specific Purposes. In R. Carter \&D. Nunan (Eds.).- The Cambridge Guide to Teaching English to Speakers of Other Languages Cambridge: Cambridge University Press. -2001. Pp. 131- 136.

6. Jones, G. ESP textbooks: Do they really exist? English for Specific or Special purpose.v.9, issue 1. - 1990. Pp. 89-93.

7. Regan, L. 20 Teaching Tips: Pair Work/Group Work. http://www.tefl.net/teaching/ teaching-tip_01.htm

\section{PЕЗЮМЕ}

Златников Валентин,

кандидат педагогических наук, доцент, Военный институт, Киевский национальний университет имени Тараса Шевченка, г. Киев

Кузнєцова Ольга,

кандидат психологічних наук, доцент, Институт филологии, Киевський национальнийуниверситет имени Тараса Шевченка, г. Київ

\section{Инновационные технологии в усвоении служебной и профессиональной лексики на иностранном языке}

В статье рассматриваются инновационные подходы и методические особенности реализации социально-коммуникативных языковых намерений на неспециальных факультетах, механизмы формирования профессионального общения на иностранном языке с позиций деятельностного подхода.

Ключевые слова: коммуникативные особенности; репродуктивное воспроизводство; средства выражения; система упражнений; дозировка трудностей; понятийный аппарат; языковые навыки; общенаучный словарь; критерий измерения знаний; навыки практического мышления; самообразование.

\section{SUMMARY}

Valentine Zlatnikov, Ph.D. (Pedagogical Studies), Military Institute, Taras Shevchenko National University of Kyiv Olga Kuznetsova, Ph.D. (Psychology), the Institute of philology, Taras Shevchenko National University of Kyiv

\section{Innovative technologies in mastering official and professional vocabulary in foreign language}

The article examines the methodological and psychological features of the implementation of socially communicative language intentions at non-specialized faculties, the mechanisms of speech formation from the standpoint of an active approach. 
Key words: communicative features; reproduction; means of expression; system of exercises; dosage of difficulties; language skills; general scientific vocabulary; the criterion for measuring knowledge; practical thinking skills; self-education. 